Journal of American Studies, 53 (2019), 3, 683-702

(C) Cambridge University Press and British Association for American Studies 2018. This is an Open Access article, distributed under the terms of the Creative Commons Attribution licence (http://creativecommons.org/licenses/by/4.o/), which permits unrestricted re-use, distribution, and reproduction in any medium, provided the original work is properly cited.

doi:10.1017/S0021875818000476 First published online 5 July 201 8

\title{
Murder on the Kansas City Special? Pullman Porters, Emotions, and the Strange Case of J. H. Wilkins
}

\author{
ROSEMARY PEARCE
}

J. H. Wilkins, an African American railroad porter for the Pullman Company, was killed while on duty in April 1930. How he met his death has never been fully determined, but the Pullman Company's investigation file exposes the dangerous and racialized emotional terrain that porters navigated daily on their journeys across the US. By examining Wilkins's death, and the work of Pullman porters more broadly, this article makes the case that white control of black emotions in occupational and public spaces was a significant characteristic of the Jim Crow era, and demands further scholarly attention.
Jog-a-long, boys, jog-a-long, boys,
Be careful when you smile,
Do the latest style,
But jog-a-long, jog-a-long boys.
Jog-a-long, boys, jog-a-long, boys,
Don't fool with goo-goo eyes,
That would not be wise,
But jog-a-long, jog-a-long boys. ${ }^{\mathrm{I}}$

John Henry Wilkins, an African American porter for the Pullman Company, was killed in the early morning of 5 April 1930 while working on the Kansas City Special from Jacksonville, Florida. ${ }^{2}$ A group of young local boys, three black and one white, found his body tied to a tree near Locust Grove, Georgia. ${ }^{3}$ A brief description of these circumstances evokes the infamous

Department of American and Canadian Studies, University of Nottingham. Email: rosemary. pearcer@nottingham.ac.uk.

I From Pullman Porters Quartette, “Jog-a-Long Boys," on Black Secular Vocal Groups, Volume I, The Twenties (I923-1919), MP 3 (Document Records, 1997, originally released in 1927).

2 J. P. Crawford, "Statement," n.d. 1930, "Illness and Death of J. H. Wilkins," signed statement. The case file referred to throughout is "Illness and Death of J. H. Wilkins," Operating Department, Series 3, Subject Files, 1930-1966, Box 6, Folder 105, Newberry Library, Chicago, Pullman Company Archives.

${ }^{3}$ Mr. H. F. Price, "Statement," 8 April ı 930, "Illness and Death of J. H. Wilkins," unsigned statement; "Pullman Porter Is Slain, Tied to Tree," 7 April 1930, "Illness and Death of J. H. Wilkins," newspaper article. 
form of lynching, in which the victim is hung from a tree or telegraph pole, often mutilated, and left on display. This scene was different. Wilkins's body was found tied loosely by his neck to the trunk of a small sapling using the sleeves of his white Pullman jacket. His body was discovered in a kneeling position, knees resting on the ground. While the reason Wilkins was bound to the tree remains uncertain, it is clear from the details that he did not die from hanging.

Wilkins's death was attributed to multiple injuries, including depressions in his skull and a wound under one arm. ${ }^{4}$ If the situation in which the body was found was not puzzling enough, the location of his body was seventeen miles from the train's nearest scheduled stop. 5 The company investigation ascertained that Wilkins had disappeared from the train between 4 a.m. and 5 a. $\mathrm{m}$. when the majority of passengers were in their sleeping berths. ${ }^{6}$ Consequently, the sequence of events that led to Wilkins's death has never been wholly established. The coroner's inquest concluded that Wilkins "came to his death as a result of causes unknown" and no one was prosecuted in connection with the incident. 7 The Pullman Company launched its own investigation, which certainly operated under motives other than seeking justice for Wilkins. Yet the case file reflects an intensive and meticulous effort by superintendents, inspectors and chief special agents of the company to piece together all possible details of the matter, if only to protect the company from accusations of wrongdoing or neglect, by establishing whether such accusations might have foundation. Outside the possibility that the records of the investigation were extensively fabricated, the company's case file constitutes the best available information on how Wilkins died. However, the inquiry also reveals various conflicting accounts of Wilkins's character, and multiple versions of the timeline leading up to and following the time of death. ${ }^{8}$

4 “E. G. Colvin to R. T. Lively," 8 April 1930, "Illness and Death of J. H. Wilkins," memorandum.

5 "Pullman Porter Strangely Slain", New York Times, 6 April I930, 5. See "F. B. Kemp to B. H. Vroman," 5 April I930, "Illness and Death of J. H. Wilkins," memorandum.

6 The Pullman Company estimate his time of death based on passengers' and other porters' witness accounts of when he was last seen. See, for example, P. W. Harvey, "Statement," 5 April i930, "Illness and Death of J. H. Wilkins," signed statement.

7 "J. J. Leary to Mr. Edw. J. Brennan," is April 1930, "Illness and Death of J. H. Wilkins," memorandum.

8 The case folder contains numerous witness statements and testimony from passengers and crew, the facts of which frequently contradict each other. See, for example, P. W. Harvey, "Statement," "Illness and Death of J. H. Wilkins," signed statement; R. Smith, "Statement," 25 May 1930, "Illness and Death of J. H. Wilkins," signed statement. 
Labour historians are the main contributors to the existing scholarship on Pullman porters, but much of the literature has engaged mainly with the porters' union, the Brotherhood of the Sleeping Car Porters (BSCP), and its journey to success. 9 These studies often mention the Wilkins case in passing, stating as fact the theory that he was lynched. ${ }^{\circ}$ Yet the file in the Pullman Company Archives, "Illness and Death of J. H. Wilkins," contains over three hundred pages of records from the investigation, and suggests that there are many other valid explanations. None of these alternative theories can be proven, but the accounts and reactions laid out in the file help to uncover something else entirely: the distinctively precarious professional environment of the Pullman porter. ${ }^{\text {I }}$ This article departs from the focus and methodology of previous labour studies through close scrutiny of the Pullman Company's file on Wilkins, as well as contextual accounts from various Pullman porter oral-history projects, to explore the emotional dynamics, challenges and risks of this work.

Although the Pullman Company's investigating agents never came to an official conclusion about how Wilkins met his death, examining their lines of inquiry exposes the racial difficulties and vulnerabilities inherent in the work of porters who spent their lives travelling the railroad. Attention to emotions in this context alters our understanding of the porters' work, as it becomes clear that the labour they performed was as emotional as it was physical, and that these demands were based on assumptions about them as black men as well as porters. The Pullman Company advertised its railroad service repeatedly using the image of a black porter's smile to establish expectations of their service, and porters' failure to perform the anticipated smiles and deference could result in verbal or physical abuse from white passengers or crew. However, the attention to white women and friendliness that was required of the role brought porters under the scrutiny of white passengers and colleagues who sought to enforce white supremacist modes of interracial contact. As a

9 Studies such as those by Beth Tompkins Bates and Cornelius L. Bynum have not only held up the BSCP as an example of a black union achieving extraordinary success within a discriminatory American labour culture, but also addressed their contributions to the broader struggle for black rights. Beth Tompkins Bates, Pullman Porters and the Rise of Protest Politics in Black America, I925-I945 (Chapel Hill: University of North Carolina Press, 2001); Cornelius L. Bynum, A. Philip Randolph and the Struggle for Civil Rights (Urbana: University of Illinois Press, 2010).

10 For example, see Larry Tye, Rising from the Rails: Pullman Porters and the Making of the Black Middle Class (New York: Henry Holt, 2004), 53; Brailsford Reese Brazeal, The Brotherhood of Sleeping Car Porters: Its Origin and Development (New York: Harper \& Bros., I 946), 56.

${ }^{1}$ The file, "Illness and Death of J. H. Wilkins," is erroneously named. There is no suggestion that ill health was a cause of Wilkins's death and the title is presumably intended to camouflage the scandalous qualities of a potential murder case. 
space both confined and mobile, the railroad car was a uniquely hazardous site of racial interaction and negotiation, conditions the r 920 black vocal group known as the Pullman Porters Quartette acknowledged in singing the advice, "be careful when you smile" to their fellow porters. Their warning becomes more relevant and poignant in the context of Wilkins's case, which highlights both the white control exercised over black emotions that was a quotidian part of the porters' work, and the physical danger of racist violence that was intertwined with that emotional control, which porters justifiably feared. ${ }^{12}$

The recent emotional turn in history has led to scholars investigating how emotions can provide new perspectives on existing areas of enquiry. Neuroscientists, psychologists and philosophers are increasingly questioning the distinction between feeling and cognition, which has enormous implications for historians who wish to better understand how individuals make the decisions that influence historical outcomes. ${ }^{13}$ In particular, diplomatic and medical historians now treat emotions as a fruitful area for investigation. ${ }^{14}$ However, so far there have been only a few small studies that examine the emotional implications for African Americans of living within a white supremacist society. For Melissa Victoria Harris-Perry, the Jim Crow system was a "powerful mechanism for the production of shame." 's Jonathan Scott Holloway addresses the feelings of humiliation stemming from segregation and racial discrimination by examining the "My Most Humiliating Jim Crow Experience" series, printed in the Negro Digest between March 1944 and June 1946. ${ }^{16}$ Holloway and Harris-Perry have initiated the important work of addressing the emotional strain of living in a segregated society, but although shame and humiliation are crucial to any discussion of African American feeling during the Jim Crow era, there is a broader context to be explored. Examining the work of porters reveals that the Pullman Company, as well as white passengers and crew, applied emotional control to black porters

12 Pullman Porters Quartette, "Jog-a-Long Boys."

${ }^{13}$ For more on the debate around the relationship between emotion and cognition, see William M. Reddy, The Navigation of Feeling: A Framework for the History of Emotions (Cambridge: Cambridge University Press, 200I), I 4-1 5.

${ }^{14}$ See, for example, Frank Costigliola, "Reading for Emotion," in Frank Costigliola and Michael J. Hogan, eds., Explaining the History of American Foreign Relations (Cambridge: Cambridge University Press, 2016), 356-74; F. Alberti, "Bodies, Hearts, and Minds: Why Emotions Matter to Historians of Science and Medicine," Isis, I00, 4 (Dec. 2009), 798-8 Iо.

is Melissa V. Harris-Perry, Sister Citizen: Shame, Stereotypes, and Black Women in America (New Haven, CT: Yale University Press, 20 I I), 108.

${ }^{16}$ Jonathan Scott Holloway, Jim Crow Wisdom: Memory and Identity in Black America since I940 (Chapel Hill: University of North Carolina Press, 2013), 40-66. 
that constituted a strand of oppression working alongside, but distinct from, more obvious forms of racial subjugation, such as segregation and job discrimination.

Arlie Hochschild's concept of "emotional labor" is central to this analysis, defined in her 1983 work The Managed Heart: Commercialization of Human Feeling as "the management of feeling to create a publicly observable facial and bodily display." ${ }^{17}$ In her study of female flight attendants, Hochschild argues that emotional labour is a job requirement that may have negative effects on an individual, because it represents an intensive effort that may produce stress and fatigue among employees. Although the study of emotional labour did not take off until the ig80s, corporation-specific emotional labour had existed long before the airlines studied by Hochschild were incorporated - the Pullman Company's emotional expectations of its porters being one example. Other sociologists have since questioned whether the effects of emotional labour are entirely negative, or as damaging as Hochschild suggests. ${ }^{18}$ However, in the case of Pullman porters, the sources suggest that the particular circumstances of their work made this emotional effort so extreme that the potential for harm through strain and exhaustion is clear.

There is a need to delineate "emotion" and "feeling" in the analysis, because the distinction between what a person felt and what they expressed is vital to understanding the emotional labour performed by porters. A feeling is a sensation that a person checks against their life experience, and then labels accordingly as, for instance, "anger" or "fear." Emotion is the outward expression of feeling, but the display could be sincere, exaggerated or contrived. ${ }^{19}$ Although in many works there is no conceptual distinction between emotion and feeling, or the terms are used differently, wherever "emotion" is used in this article it refers to an outward expression of a feeling, and where "feeling" is used it refers to a sensation that has been experienced and labelled by the individual in question.

The article will first contextualize the geographical and historical environment of the Pullman car, which is essential to fully understanding the Pullman porters' work. It will then examine the Wilkins case in greater detail, including the difficulties that Wilkins and other porters faced in

${ }^{17}$ Arlie Russell Hochschild, The Managed Heart: Commercialization of Human Feeling (Berkeley: University of California Press, 2012; first published 1979), 7.

${ }^{18}$ See Blake E. Ashforth and Ronald H. Humphrey, "Emotional Labor in Service Roles: The Influence of Identity," Academy of Management Review, I 8, I (1993), 88-i I 5.

19 These definitions are based on a summary given by Eric Shouse, which builds on those given in Brian Massumi's introduction, entitled "Notes on the Translation and Acknowledgements," to Gilles Deleuze and Fèlix Guattari, A Thousand Plateaus: Capitalism and Schizophrenia (Minneapolis: University of Minnesota Press, 1987), xvi. See Eric Shouse, "Feeling, Emotion, Affect," M/C Journal, 8, 6 (2005), 2-4. 
performing their duties and adhering to continually shifting racialized expectations of their behaviour and emotions, particularly in their relationships with white female passengers. Finally, the article will consider the Pullman porters' famous smile, and the implications of porters' emotional labour for scholarly conceptions of oppression in the Jim Crow era. It argues that, ultimately, the porter's work was difficult or impossible to reconcile with the emotional expectations placed on them. Adhering to the Pullman Company's demands of porters' emotions did not necessarily safeguard their jobs, or their lives.

The role of the Pullman porter was an almost exclusively African American occupation, from just after Emancipation until the demise of the Pullman Company in $1969 .{ }^{20}$ It is not quite true that Pullman Company founder George Pullman hired his porters directly out of slavery, but it is well documented that the first porters in the i 870 s were largely former slaves who did not shy from the same kind of work they had performed as domestic slaves: shining shoes, cleaning, carrying heavy luggage. ${ }^{21}$ For virtually the entire time that Pullman porters rode the rails, segregation was the law of the land - figuratively or literally, depending on period and region. The vast majority of Pullman passengers were white, as were the conductors, which created a situation inevitably fraught with racial tension. Occasionally these tensions erupted into violence, of which Wilkins could have been a victim.

The work environment of the Pullman car sometimes recalled the racial hierarchies of slavery, even decades into the twentieth century when Wilkins was working on the railroad. Black porters performed more physical labour for considerably less pay and longer hours than white Pullman conductors. $^{22}$ A porter could not be promoted to conductor, although some porters

${ }^{20}$ At certain times, the occupation also included other immigrant groups. For example, in I 944 a newspaper columnist accused BSCP of discriminating against Filipinos, and received a reply from Milton P. Webster, international vice president of the BSCP, who wrote that "a substantial number" of their members in Chicago were Filipino, and that they also had Mexican porters in their ranks. Milton P. Webster, "An Open Letter to Mr. Edwin A. Lahey of the Chicago Daily News in Connection with Article 'Finds Race Discrimination Evil Not Confined Solely to White People'," I 8 April 1944, "Correspondence, 1925-1969, cont.," Records of the Brotherhood of the Sleeping Car Porters, Part I, microfilm, Chicago History Museum, Reel 7, Frame ooor.

21 “G. A. Kelly to Mr. Crawford," I2 Nov. 1935, "Porters, 1925-1955," Public Relations Department, History Files, I860-1968, Box I, Folder 71, letter, Newberry Library, Chicago, Pullman Company Archives; Tye, Rising from the Rails, 22-23.

${ }^{22}$ For a comparison of Pullman porter, maid and conductor wages see Melinda Chateauvert, Marching Together: Women of the Brotherhood of Sleeping Car Porters (Urbana: University of Illinois Press, 1998), 27. There were two types of conductor on services with Pullman cars: a Pullman conductor but also a train conductor responsible for the whole train. Unless stated otherwise, mentions of conductors refer to Pullman conductors. 
could become "porter-in-charge" when necessary, which meant that they performed the conductors' duties in addition to their own for a small amount of extra pay. ${ }^{23}$ Company handbooks stated that the conductor held "full control and authority" over his crew, and according to Pullman Company vice president O. P. Powell, overseeing the porters' service to passengers was the conductors' "most important duty." 24 Porter Virgil Orite Smock, who worked for Pullman between 1936 and 1960, recalled that one conductor he worked with, from Mississippi, attempted to re-create plantation culture on the Pullman car:

I don't know whether he owned a plantation or not, but he looked on his porters as his boys, and nobody jumped on him. I don't care if the superintendent got on there, if you started harassing, he said [with a deep southern drawl], "Now, wait a minute. That's my boy. Now, ah, if you have anything to say to him, you talk to him when he ain't on these cars. When he's on here, he belongs to me, and I don't want nobody running over him." 25

In Smock's recollection, the southern conductor assumed a slaveholder's paternalistic attitude towards the porters, considering himself their owner and protector. In the days before a strong union emerged, the porters' seniority rights could be overridden by conductors who demanded to work with favoured porters, a situation which further entrenched the power of white conductors over black livelihoods. ${ }^{26}$

The sometimes strained relationship between porter and conductor was intensified by racial mores that altered from state to state, and town to town, that the train passed through. Porters had to consider the geographical origins of the conductors they were working with as well as the passengers they were serving, adjusting their interactions with them accordingly:

it was a custom for the southern porters to say "yes and no sir" to the conductors, the white conductors. And these northern porters ... this particular one didn't do that. And this conductor wrote him up he wrote - oh, he wrote a letter about that long, the things this porter had done. ${ }^{27}$

${ }^{23}$ Jack Santino, Miles of Smiles, Years of Struggle: Stories of Black Pullman Porters (Urbana: University of Illinois Press, 1991), 24. David D. Perata, Those Pullman Blues: An Oral History of the African American Railroad Attendant (New York: Twayne Publishers, 1996), 8.

24 "Instructions for Employees on Cars of the Pullman Company," I 903 , Pullman Company Instruction Books, 1872, 1903, 1906, I905, 191 I, Operating Department, Series 3, Subject Files, 1930-1966,. Box 2, Folder 23, Employee Handbook, Newberry Library, Chicago, Pullman Company Archives, I5; "O. P. Powell to F. B. Kemp," 8 May 1930, "Illness and Death of J. H. Wilkins," memorandum.

${ }^{26}$ Cliff Kuhn, Harlon Joye and Bernard West, Living Atlanta: An Oral History of the City, 1914-1948 (Atlanta: University of Georgia Press, 2005), 57-86.

27 Greg Leroy interview with James A. Martin, Interviews about the Brotherhood of Sleeping Car Porters, compact disc (Chicago History Museum, n.d. 1978). Transcribed by the author. 
As this anecdote told by porter James A. Martin acknowledges, failing to conform to the conductors' expectations of deference from porters might have resulted in a formal reprimand.

Interactions with passengers, too, were sometimes challenging to negotiate; the behaviour of the same group of passengers was known to shift based on the train's location:

porters talk of dreading to go "through the tunnel" that runs under the Potomac River from Washington, D.C., to Virginia. A passenger might start calling porters "nigger" instead of "porter." Once, a passenger insisted that a Negro passenger be removed from the coach as soon as the train had entered the South, even though he had not complained previously. ${ }^{28}$

Porter and BSCP leader Milton Price Webster also experienced this phenomenon. He admitted in a union meeting that whenever he crossed the Potomac he got "a kind of deep feeling, a funny feeling," which always left him "silent." ${ }^{29}$ Wilkins was from Kansas City, Missouri, and was therefore accustomed to racial norms different from those of Deep South states. The differences could be significant; Pullman porter and activist E. D. Nixon remembered being stunned by the disparity between interracial customs in Missouri's St. Louis and his hometown of Montgomery, Alabama, recalling, "I was dumbfounded and shocked down to my toes when I got up there and found black people and white people sitting down at the same table eating in the railroad station." $3 \circ$ One of the most important racial norms that Wilkins and other porters would have had to bear in mind on journeys in the Deep South was the intense taboo against intimate or sexual contact between black men and white women. Showing interest in a white woman in the South, or simply appearing to, could have cost Wilkins his life.

In the days after Wilkin's body was found there was much speculation in both the white and black press about the causes of his death. In general, white newspapers refrained from pushing one single theory, but black newspapers such as the Afro-American and the Kansas City Call suggested that Wilkins was lynched. ${ }^{31}$ The Afro-American went as far as citing a motive,

28 Santino, 28.

29 Joseph F. Wilson, ed., Tearing Down the Color Bar: A Documentary History and Analysis of the Brotherhood of Sleeping Car Porters (New York: Columbia University Press, 1989), 275.

30 Donnie Williams and Wayne Greenhaw, The Thunder of Angels: The Montgomery Bus Boycott and the People Who Broke the Back of Jim Crow (Chicago: Lawrence Hill Books, 2006), 28.

31 "Lynching of Porter Points to Train Crew," 17 April 1930, "Illness and Death of J. H. Wilkins," newspaper article; "No Clue to Pullman Porter's Lynchers," Afro American (Baltimore), i9 April I930, 2, at http://news.google.com/newspapers? nid=UBnQDrsgPskC\&dat=I93004I9\&printsec=frontpage\&hl=en;, 2; "Deep Mystery in Porter Killing," 25 April ı930, "Illness and Death of J. H. Wilkins," newspaper article. 
reporting, "colleagues of Wilkins claim that the white train crew stopped the train at Locust Grove and lynched Wilkins. They were angry at him, they said, because, unable to find a berth for a white woman, he sought to appease her and smiled at her." ${ }_{32}$ Witness statements in the Pullman Company file do not support this claim. According to testimony by other porters and the rest of the train staff, Wilkins left the train in the early morning when the majority of passengers and many crew would have been asleep, but none of the interviewed passengers from Wilkins's car mentioned difficulties with a passenger attempting to secure a berth. None of the witnesses among passengers or crew members acknowledged a train stop at Locust Grove. While the Pullman Company's collected testimony does not conclusively demonstrate that the train crew did not make an unscheduled stop to lynch Wilkins, there is a lack of evidence to support the lynching theory, beyond the AfroAmerican's unnamed sources.

Despite the paucity of solid evidence, this version of events was entirely plausible to African American communities that took an interest in the story. The particular detail of Wilkins having been tied to a tree, when reported without specifics, naturally gave the impression of his death as an archetypal southern lynching. Some of those who were close to the case also believed some version of this story, such as an off-duty white conductor named W. H. Burgum who was traveling in Wilkins's car. Burgum confidentially told Pullman investigators that he was "inclined to believe that Porter Wilkins was caught in Lower 7 with the woman and forced out the window." 33 In the context of I930s Georgia, it was completely credible that he had been killed because he had become too intimate with a white woman, or even just displayed what others considered to be undue interest or friendliness. ${ }^{34}$ That so many were convinced that Wilkins had been lynched can be explained through a more detailed examination of the racial, cultural and social dimensions of the porters' place of work.

The Pullman car was a unique space of racial negotiation, due to two main factors: (I) the cars were confined spaces, and (2) they were nearly always in motion. The car's movement across the nation resulted in continually shifting racial customs and laws, but there was also the fact that the Pullman car could

32 "No Clue to Pullman Porter's Lynchers," 2.

33 “J. J. Leary to Mr. Edw. J. Brennan," 2 I May 1930, "Illness and Death of J. H. Wilkins," memorandum.

${ }^{34}$ According to the Tuskegee Institute's records of lynching for each state, Georgia saw the second-highest incidence of lynching of African Americans between 1882 and 1968 . Mississippi saw the highest. Doug Linder, "Lynchings: By State and Race, I 882-1968," Tuskegee Institute, at http://law2.umkc.edu/faculty/projects/ftrials/shipp/lynchingsstate. html., accessed 25 Oct. 2016. 
not be safely exited while moving at speed. The claustrophobic nature of the space inevitably had an impact on social interactions, particularly those involving white women. According to James T. Steele, who worked for the Pullman Company on the buffet car between 1936 and 1960,

So being on a car is just like being in the South. When you're walking down the street and a white lady's coming this way, you're supposed to get your black self outta the streets and let her go by. Then you get back on the sidewalk [laughs] That's true!35

Here Steele recalled the danger created by forced proximity. In the limited space of the Pullman car, black male bodies and white female bodies risked physical contact, thereby breaking the fundamental tenet of southern racial interaction. The confinement and motion of the Pullman car created a space in which the conditions of segregation were especially tenuous and therefore policed particularly vigilantly by white males. Former president of the prestigious black Morehouse College Dr. Benjamin Mays recollected being paraded through the train by white men and boys at gunpoint after he had boarded a train at Birmingham, Alabama and attempted to travel in the Pullman car for which he had bought a ticket. ${ }^{36}$ A porter named E. Patrick gave a statement attesting that a train conductor had beaten him and had him arrested for drunkenness after discovering him talking to a group of white sailors on the way back to his own Pullman car. Patrick attested that the conductor asked him, "don't you know that a nigger is not suppose $[s i c]$ to be riding in the white coaches with white people in the state of Mississippi." ${ }_{77}$ Stories like these demonstrate the extent to which white train staff and passengers regulated what they considered to be the correct racial order within the Pullman car.

The Pullman Company also policed the cars, by hiring undercover agents known as "spotters" to ride as passengers and record their porters' responses. After reports of poor service or wrongdoing, Pullman Company officials would put a porter on the list for being "checked." ${ }^{38}$ While many of these mystery passengers were hired to catch porters stealing, white female spotters were recruited to express sexual interest. ${ }^{39}$ The Pullman Company must have

35 Perata, Those Pullman Blues, 80.

${ }^{36}$ Benjamin E. Mays, Born to Rebel: An Autobiography (Athens: University of Georgia Press, 2003), 94-95.

37 "Porter E. Patrick to Mr. Langehennig" 4 April 1945, "Porters," Employee and Labor Relations Department, Chief Special Agent, Series I, Railroad Police Incident Files, 1944-1945, Box I, Folder I4-1 5, signed statement, Newberry Library, Chicago, Pullman Company Archives.

38 "H. R. Lary to Mr. F. R. Callahan," 30 Aug. 1945, "Complaints - Porter Service, 19361959," Employee and Labor Relations Department, General Labor Files, I 900-1970, Box 29, Folder 671, Report, Newberry Library, Chicago, Pullman Company Archives.

39 Perata, 78; Tye, Rising from the Rails, 103. 
considered setting up these "honey traps" vital to their business; Steele pointed out that they "would pay you $\$ 77.50$ a month, and then pay $\$ 2,000$ to get something on you." ${ }^{\circ}$ Between November 194I and August 1944, twentyeight porters were dismissed from the company for offences characterized as "familiarity with women." The details of the offences ranged from the specific - "entered lady's berth at night" - to the vague - "annoyed woman passenger." 41

Steele recounted a story in which a fellow porter was guilty of being seduced by a spotter. The inspector, who had been waiting to catch the porter getting into the spotter's berth, fired him immediately. The practical reasons for which the Pullman Company hired spotters become clear in another of Steele's anecdotes: a sixty-seven-year-old porter named Forsythe was accused of twice having sex with a female passenger, who then took the Pullman Company to court. According to Steele, a note from a white doctor saved Forsythe, confirming that he had been impotent for years. While Steele did not give enough detail for the facts of this story to be verified, documents in the Pullman Company archives show that the company did go to court over lawsuits of this kind. ${ }^{42}$

Steele also described a time when he was targeted by a female passenger, and had to ask the train conductor to go into the woman's room with him to avoid potential accusations. ${ }^{43}$ Steele admitted that he had to suppress his feelings in such situations: "You got to be strong, see, because I'm gonna tell ya: temptation is great." 44 The consequences of being accused of sexual contact with passengers varied according to where the event occurred. Steele's experiences were of Los Angeles-based runs, where an accusation from a passenger could mean immediate dismissal, especially before the BSCP became powerful enough to demand a fairer hearings process. ${ }^{45}$ Steele observed that, once the union became recognized, it provided some protection from accusations of inappropriate behaviour towards female passengers:

When they got strong, then you had a chance. But before then, if this white woman say you felt her legs or you tried to do so-and-so to her, they would take her word and pay

${ }^{40}$ Perata, 78. It is not clear where Steele got the figure of $\$ 2,000$ from, it may be entirely fictional, yet his remark makes the important point that the Pullman Company were financially invested in checking porters' behaviour.

${ }^{41}$ "List of Porters and Conductors Dismissed for Familiarity with Women," n.d., "Porters and Conductors - Discharge - "Familiarity with Women Passenger", I940-1958," Labor Relations Department, General Labor Files, 1900-1970, Box 24, Folder 550, Newberry Library, Chicago, Pullman Company Archives. ${ }^{42}$ Ibid. ${ }^{43}$ Perata, $78 .{ }^{44}$ Ibid., 79.

${ }^{45}$ Leroy interview with Martin; Milton P. Webster, "Legal Definitions of the Phrase "Beyond a Reasonable Doubt,," i i Nov. I953, "Beyond a Reasonable Doubt," Records of the Brotherhood of the Sleeping Car Porters, Part 3, microfilm, Chicago History Museum, Reel 2, Frame 0719. 
her so much money and kick your ass out in the streets ... But if you didn't have a union then, you ain't got no voice. ${ }^{46}$

On runs into the South, however, the sexual taboo was so strong that being lynched was an easily conceivable outcome.

Porters were not only vulnerable to accusations of improper behaviour, but were also victims of unwanted advances themselves. In I 940 Benjamin Sumner Welles, white diplomat and foreign-policy adviser to President Roosevelt, solicited paid sex from a Pullman porter named John Stone. When Stone refused, Welles called in other porters individually, who each in turn refused him. White House Secret Service told the porters to maintain their silence, but by 1943 Welles's enemies had used the information to remove him from his post as undersecretary of state. ${ }^{47}$ The requirements of porters to be friendly and aim to please to passengers, combined with an imbalance of power with regard to their class and occupational status, suggest that porters were vulnerable to the desires and whims of passengers, and could come under pressure to act in ways that went beyond the normal scope of their role, and against their own wishes. There is no evidence that the porters in question were punished for refusing Welles's request, but this was not always the case. According to porter Morse Bing Jr.'s statement for the Pullman Company, in October I 945 he was racially abused, beaten, and cut with a glass bottle by sailors after refusing to dance for them. ${ }^{48}$

The clear peril of interracial associations for porters explains why the black press leapt to the conclusion that Wilkins was lynched. Witnesses also made the connection, and noted that Wilkins had been talking to, and possibly flirting with, the white woman in berth lower 7.49 The interactions between Wilkins and the woman were observed and noted by the other passengers; W. H. Burgum noticed Wilkins pick up her handbag and take it to her in the ladies' dressing room. "In my opinion," he wrote, "they were more familiar than colored porter or white woman passenger should be." 50 The woman, who

46 Perata, 80-8I.

47 For greater detail see Christopher A. Parkes, "The Welles of Loneliness: Sumner Welles and the Creation of American Foreign Policy" (London School of Economics and Political Science, 2015), 199-202, 216; Douglas M. Charles, Hoover's War on Gays: Exposing the FBI's "Sex Deviates" Program (Lawrence: University Press of Kansas, 20 I 5), 36-68.

48 "Morse Bing Jr. To G. W. Kelly," 3 Nov. I945, "Brutality," Records of the Brotherhood of the Sleeping Car Porters, Part 3, microfilm, Chicago History Museum, Reel 2, Frame 0766.

49 P. W. Harvey, "Supplement Statement," 7 April ı 930, "Illness and Death of J. H. Wilkins," signed statement; "J. J. Leary to Mr. Edw. J. Brennan," 2 I May I 930, "Illness and Death of J. H. Wilkins," memorandum; "Assistant Superintendant Lively to Mr. F. B. Kemp," I 2 April ı930, "Illness and Death of J. H. Wilkins," memorandum.

so W. H. Burgum, "Statement," s April i 930, "Illness and Death of J. H. Wilkins," signed statement. 
gave her name as Mrs. George Henderson, was described by passengers as "bold," "tough," and "apparently of no refinement"; Mrs. Rasmussen, who occupied lower 4, alluded to her possibly being a prostitute, claiming she was "evidently a sport as she has that 'hard look' so characteristic of such women." si In fact, the Pullman Company investigation uncovered evidence that Mrs. George Henderson - or Edith R. Reynolds, as they discovered her real name to be - had killed her husband with a knife five years previously and was known to have stabbed a number of others. ${ }^{52}$ Though pure speculation, considering the possibility that Reynolds attacked Wilkins in the night helps to expose the difficult racialized sexual dynamic between porter and white female passenger. Under attack, Wilkins may not have felt able to call out or seek help for fear of being thought the attacker. The "black rapist" was, after all, a powerful trope in public imagination, which made black men more vulnerable to violence, and also less able to seek help or recourse from violence. In the restricted space of the Pullman car, the inability to escape violent confrontations intensified the danger for porters.

Despite white society's preoccupation with physically separating black and white Americans, porters were expected to attend to white passengers on the train in ways that were often intimate: brushing off the shoulders of men's suits, waiting on passengers with food and drink, listening to their troubles, taking care of their children. ${ }^{53}$ Garrard Wilson Smock, one of three brothers who worked as porters, recalls passengers who were perfectly comfortable asking him to retrieve their belongings while they sat on the toilet. His brother George suggested that putting inebriated women to bed was not an uncommon duty for a porter. ${ }^{54}$ Witness statements from passengers who watched Wilkins and Reynolds's exchanges, like that of W. H. Burgum, reveal the difficulty for porters in pleasing white passengers without crossing the line into what could be perceived as overfamiliarity. The newspaper report that suggested Wilkins had been lynched because he had "smiled" at a white woman, though limited as evidence for what happened to Wilkins, nevertheless underlines a key paradox in the life of a Pullman porter: the friendly emotional expression he was required to perform as part of his work was the same expression that could jeopardize his career and his

51 “J. J. Leary to Mr. Edw. J. Brennan," i 5 May i 930, "Illness and Death of J. H. Wilkins," memorandum; "Mr. Wm Venn to Mr. F. B. Kemp," s April ı930, "Illness and Death of J. H. Wilkins," memorandum.

52 She is also known as Edith Hansen in some of the documents, resulting from a different marriage.

53 See, for example, W. A. Rice and Henry Lee, "Let a Pullman Porter Give You a Tip," Pageant, Feb. 1951, "Porters, 1925-1955," Public Relations Department, Series 3, History Files, I860-1968, Box I, Folder 7 I, magazine article, Newberry Library, Chicago, Pullman Company Archives. 
safety. 55 Porters referred to their work as "miles of smiles" but were aware of the delicate parameters they worked within. The origins of these expectations, and the racial complications entangled with them, bear further scrutiny in order to fully expose the impossible situation that Wilkins faced in his contact with Mrs. Reynolds.

The Pullman Company explicitly promoted the porters' smiles in advertising as part of the Pullman travel experience, just as in the latter half of the twentieth century airlines sold the promise of smiling flight attendants. ${ }^{56}$ The company made it clear in employee instruction books that it expected both white conductors and black porters to give a high level of personal service to all passengers, male and female, and to be "obliging and courteous at all times." 57 The porters, however, bore the vast majority of the customer interaction, and therefore most of the emotional labour. In addition, they carried the burden of expectations that developed out of racial norms established during slavery; the trope of the happy slave that featured in proslavery propaganda before the Civil War endured in the public consciousness long into the twentieth century. The Pullman Company exploited this association, claiming in public-relations copy that "porters are regarded as a dependable and indispensable friend," and possessed an "instinctive racial fondness for children," which was a reassurance to the public that porters were harmless, avuncular men who could take care of children and protectively watch over young women travelling alone. ${ }^{8}$ George Pullman himself is reported to have believed that African Americans possessed a singular personality type

5s "No Clue to Pullman Porter's Lynchers," Afro American (Baltimore), is April 1930, 2.

${ }^{56}$ See the Pullman Industrial Heritage Archives online for advertisements featuring smiling Pullman porters. For example, "How Many People Make a Good Night's Sleep?", 1948. advertisment, Pullman State Historic Site, Industrial Heritage Archives, at http://pullmanmuseum.org/cgi-bin/pvm/newMainRecordDisplayXML.pl?recordid=I I 29I, accessed 2 I July 2016; "All Aboard ... For a Happy Vacation Go by Train!", 1949, advertisment, Pullman State Historic Site, Industrial Heritage Archives, at http://pullman-museum.org/ cgi-bin/pvm/newMainRecordDisplayXML.pl? recordid=9376, accessed 2 I July 2016. For more about airline marketing of smiles see Hochschild, The Managed Heart, 5.

57 "Instructions to Conductors," 1926, Conductors Instruction Books, 1926, 1935, I939, 1 952, Series 6, Employee Instruction Books, I 872-1956, Box 2, Folder 2 I a, company handbook, Newberry Library, Chicago, Pullman Company Archives; "Instructions to Porters," 1925, Porters Instruction Books, I925, 1935, Series 6, Employee Instruction Books, I $872-$ 1956, Box 2, Folder 33, company handbook, Newberry Library, Chicago, Pullman Company Archives.

58 "The Pullman Porter", n.d., "Porters, I925-1955," Public Relations Department, Series 3, History Files, I 860-1968, publicity copy, Newberry Library, Chicago, Pullman Company Archives, 3-4; Jake Wolf and Weldon Melick, "A Pullman Porter Speaks His Mind," Coronet, April 1948, "Porters, 1925-1955," Public Relations Department, Series 3, History Files, I860-1968, Folder I, magazine article, Newberry Library, Chicago, Pullman Company Archives, 82. 
that made them especially suitable for waiting on his white passengers. 59 Yet surveillance that the company performed on porters, through employing spotters to ensure that they did not get too intimate with the female passengers, contradicts this position; fear of the black sexual predator, as depicted in D. W. Griffith's igis film The Birth of a Nation, still resonated within white society. That African Americans were considered uniquely qualified for the role of Pullman porter, and at the same time not entirely trusted, means that porters were subject to two contradictory expectations of their behaviour and emotional expression. ${ }^{60}$ Wilkins and other porters were placed into a precarious situation, navigating between these assumptions in their performance of emotional labour. Hence the Pullman Porters Quartette's warning to "be careful when you smile," and not to "fool with goo-goo eyes," reminded porters of who might be watching their friendly smiles to white women, and what the potential consequences might be.

Despite the fear of interracial familiarity and suspicion of porters' motives, white passengers considered the porters' smile to be as integral to the job as any of his physical duties. Porter and activist E. D. Nixon explained, "you had to be so careful, because anyone getting on the train can just roll up and say you didn't shine his shoes or brush him off when he got on and he didn't like your attitude or you didn't smile when you spoke to him."61 Porters were punished either for failing to smile or for expressing undesirable feelings such as irritation or anger. A reprimand from the company often took the form of an economic penalty; the porter would either be assigned a run that was known to yield few tips, or would not be assigned any run at all for a particular period. ${ }^{62}$

However, porters were also subject to informal punishment by white conductors who were dissatisfied with the porters' work, which could take the form of being ejected from the train. After Wilkins's death, a group of porters wrote a letter of complaint addressed to Mr. L. S. Hungerford, the vice president and general manager of the Pullman Company, and copies were sent around to different districts to gain porters' signatures. In addition to calling for a "rigid investigation," the porters asked the Pullman Company to take more effective steps to protect them:

59 Beth Tompkins Bates, Pullman Porters and the Rise of Protest Politics in Black America, I925-1945 (Chapel Hill: University of North Carolina Press, 2001), 17.

${ }^{60}$ For more on the Pullman porter and stereotypes in popular culture, see Santino, Miles of Smiles.

${ }^{61}$ Interview with E. D. Nixon, in Jack Santino and Paul Wagner, Miles of Smiles, Years of Struggle, VHS (San Francisco: California Newsreel, 1983 ).

${ }^{62}$ Santino, Miles of Smiles, 36, 47. 


\section{Rosemary Pearce}

We wish to call attention to the habit very often practiced in the South, where Pullman porters for some misdemeanour are often taken from the cars and left at some small town, in many cases without proper means to get back to his terminal. We believe that it is no more than fare [sic] that these porters be returned to their terminals. Under the present system a porter has very little protection unless the Company will come to his rescue in such cases. ${ }^{63}$

Clearly, porters who signed the letter suspected that Wilkins could have died after being ejected from the train at Locust Grove for a minor infraction. According to a I944 study carried out by the Pullman Company, the primary reason that porters were put off trains was "insubordination" towards a conductor or inspector, who then would take "revenge on the porter by unloading him in an out-of-the-way place."64 Although the Pullman Company discouraged this kind of improvised discipline, its widespread practice, particularly in the South, highlights how circumspect porters had to be in keeping their behaviour and emotional expression in line with the conductors' expectations, to avoid accusations of "insubordination."

However, interviews with retired Pullman porters demonstrate that the restricted space of the Pullman car made it difficult to hide emotions considered undesirable to the work, such as anger, dejection and pride. As a porter with a self-confessed "Irish temper," George Henry Smock was in the unusual position of being fired twice - and was written up by his manager at least once - for failing to perform his emotional labour correctly. ${ }^{65}$ The mildest reaction of anger he described came after he had painstakingly squeezed lemons to make lemonade for a passenger:

So I make up the lemonade, and I take it out there to him, and he asks how much he owed me, and told him - I think it was 3 I $\$$ - and he gave me $40 \$$ and said "Thank you," which was $9 \$$ for all the work I was doing. And I picked it up, and I went by the buffet. I sailed the doggone tray - the little stainless steel tray - sailed the tray into the kitchen, and you know all the kitchen is metal anyway, and you could hear the sucker ring from now on end! ${ }^{66}$

The passenger was a spotter, hired by the Pullman Company to test the customer service given by the porters, and Smock was formally reprimanded. In contrast to other incidents he described, however, it appears he made some

63 "Porters of the Louisville District to Mr. L. S. Hungerford," 22 April 1930, "Illness and Death of J. H. Wilkins," letter.

${ }^{64}$ H. R. Lary, "Subject: A Study of the Causes Related to the Removal of Porters from Trains En Route," 22 Dec. 1944, "Study - Causes Related to Removal of Porters from Train en Route, I 944," Employee and Labor Relations Department, Series 3, General Labor Files, 1900-1970, Box 24, Folder 553, report, Newberry Library, Chicago, Pullman Company Archives.

65 Perata, Those Pullman Blues, 7-8.

${ }^{66}$ Ibid., 7 . 
attempt to regulate his emotions in the passenger's presence. He did not describe saying or doing anything to betray his anger to the passenger directly, but the close proximity of the metal kitchen gave away Smock's annoyance to the spotter. In the confined space of the railway car, there was little opportunity for private expression of feeling. Additionally, porters' working hours were notoriously long and sleep denial considered normal - a situation that could not have made the performance of a constantly cheerful disposition easier. ${ }^{67}$ In this light, Wilkins's clean record of eleven years of Pullman service before his death is impressive. ${ }^{68}$

For many porters, the majority of their pay came from passenger tips rather than the basic Pullman Company salary, which explains why Smock became so angry about a tip that seemed disproportionate to the effort he spent. The company's emphasis on smiles and deference, in combination with the tipping payment model, made porters more susceptible to emotional strain that came with maintaining the correct emotional expression when insulted or abused. For porters who were assigned the right runs and could keep smiling through anything, the tipping system allowed them to make a decent living and own a house and a car. ${ }^{69}$ Others were not so lucky. Before labour leader A. Philip Randolph founded the BSCP in 1925, porters had no independent union to work in their interests. In any case of suspected wrongdoing, a porter had no official recourse and was forced to simply accept the Pullman Company's judgement and punishment. ${ }^{70}$ However, from the time the Pullman Company was forced to recognize the union in 1935, the BSCP worked to provide defence for porters accused of transgressions by passengers or other railway staff. ${ }^{7 \mathrm{I}}$ They also managed to make significant salary increases, making porters less dependent on tips and therefore easing the strain of the emotional labour required to please difficult passengers.

E. D. Nixon related a revealing anecdote about a time in Mobile, Alabama when star baseball player Babe Ruth tipped him and found Nixon's "thank you" to express insufficient gratitude: "You know what he said? He said

${ }^{67}$ Alan Derickson, “'Asleep and Awake at the Same Time': Sleep Denial among Pullman Porters," Labor: Studies in Working-Class History of the Americas, 5, 3 (2008), I 3-44.

${ }^{68}$ B. H. Vroman, "Memorandum," 5 April 1930, "Illness and Death of J. H. Wilkins."

69 Tye, Rising from the Rails, 77.

70 There are some cases of porters keeping or being given back their jobs after a family member went to their local Pullman office to speak on their behalf. George Henry Smock once engaged in a fight with a white platform man in Texas but avoided losing his job after his father Gerrard, a longtime porter for the company, reprimanded his superior for sending his son south against his wishes. Perata, i I. Mrs. J. B. Tucker also successfully demanded her husband's job back after he was fired for her union activities. Santino, Miles of Smiles, 45 .

${ }^{71}$ Webster, "Legal Definitions of the Phrase 'Beyond a Reasonable Doubt'." 
'Nigger, you don't know how to pull your hat off when a white man gives you a tip?' I said, 'Mister, if you expect me to climb for fifteen cents, you can keep it.' And everybody just hollered." ${ }^{2}$ The way Nixon told it, with a punchline that made everyone laugh, allowed him to come off better in the exchange than Ruth without causing a serious confrontation. Nevertheless, Nixon was still referred to as "nigger," and he still had to address the man who insulted him as "Mister." Unable to safely express anger at the slight, Nixon instead resorted to humour to defuse the situation and keep his dignity intact, a response that evokes James Scott's explanation of the "micro" power struggles of "infrapolitics," in which the subordinate group resists oppression through everyday acts, in this case a joke that undermined the dominant party. ${ }^{73}$ In order to remain employed, porters were required to hide any militant or activist tendencies, which conflicted with their duty to make white passengers feel at ease. ${ }^{74}$ Challenges to the racialized expectations of emotional expression, such as Nixon's refusal to express exaggerated gratitude for his tip, demonstrate a broader, subtler form of resistance that allowed some porters to keep their job and their self-respect.

The porters were therefore not activists in the traditional sense while at work, but involvement in community activist organizations provided an opportunity to channel unexpressed frustrations into working for change. At an early church gathering about the Montgomery bus boycott, E. D. Nixon angrily called for attendees to stand up against potential criticism and retaliations from the white community in Montgomery in 1955, telling the church ministers, "it's time to take the aprons off." 75 For Nixon, the apron he wore as a Pullman porter represented a side of him powerless to complain overtly, or react in anger. The emotional labour involved in his work,

${ }^{72}$ Williams and Greenhaw, The Thunder of Angels, 29-30.

${ }^{73}$ James C. Scott, Domination and the Arts of Resistance: Hidden Transcripts (New Haven, CT: Yale University Press, 1990), 197.

${ }^{74}$ The Pullman Company sometimes cited passengers' comfort as a reason to dismiss porters who were involved in organizing for the BSCP. One of reasons given for the dismissal of C. L. Dellums when he became a union organizer was that he distributed BSCP leaflets "to the annoyance of our passengers," but concerns were also mentioned that Dellums could "incite our Patrons against the Company." O. P. Powell, "Subject: Activities, Services and Dismissal of San Francisco District Porter C. L. Dellums," n.d. I927, "Organizers," Employee and Labor Relations Department, Series 4, Labor Negotiation and Agreement Files, 1920-1969, Box 17, Folder 432, memorandum, Newberry Library, Chicago, Pullman Company Archives.

75 Taylor Branch, Parting the Waters: America in the King Years, 1954-63 (New York: Simon and Schuster, 1988), I 36; Virginia Foster Durr and Hollinger F. Barnard, Outside the Magic Circle: The Autobiography of Virginia Foster Durr (Tuscaloosa: University of Alabama Press, 1990), $28 \mathrm{I}$. 
then, was impetus to voice his grievances where he could, motivating his decades of work to fight racial discrimination in his hometown. ${ }^{76}$

Nixon's story is just one example of why scholars should give attention to the racialized emotional control that African Americans experienced during the Jim Crow era. Understanding the severe restrictions on porters' emotional expression provides a valuable new perspective on Nixon's outburst against the Montgomery ministers, and his motivations as an activist. The circumstances of Wilkins's death, too, are illuminated through consideration of the perilous and contradictory emotional expectations placed on the intertwined identities of porter and black man. Many questions remain unanswered: was Wilkins murdered, lynched or the victim of an accident? Why was his body found so far from the tracks? Who tied him to the sapling with his Pullman jacket? The Pullman Company's inquiry, though extensive, never set out to bring a murderer to justice but to protect the legal interests of the company. Yet the investigation has also highlighted the stakes involved for porters in performing the required emotional labour, and the associated risks found in the ever-changing intersections of race and place. Speculation around Wilkins's interactions with Edith Reynolds demonstrates that the porters' performance of emotional labour was a dangerous tightrope walk, navigating changing racial expectations and the blurred line between good service and overfamiliarity as the train travelled from state to state. Failing to perform emotional labour to a standard considered adequate by passengers or crew could have put Wilkins at risk of racial violence, or of being removed from the train in a dangerous place. Alternatively, suspicions about black men as aggressive sexual predators could have prevented Wilkins from seeking help when attacked by a white woman during the night. White attitudes and surveillance of porters brought to bear an extreme and sometimes contradictory pressure to maintain a friendly, but not too friendly, countenance with white passengers throughout the long journeys on which they worked.

Racialized emotional labour was not limited to the experience of railroad porters, but was a significant part of other service roles dominated by African Americans: waiting staff, maids, cooks, busboys and elevator operators, for example. The Pullman car is, however, a site in which this phenomenon is particularly visible and intense. This is partly because racial interactions between porter and passenger were required, frequent and contained within a relatively small space, and partly because the Pullman Company's records tell such a vivid story of which kinds of emotions and behaviours were expected of porters, and which the company was most determined to curtail. Nevertheless, while the emotional requirements of businesses like the

${ }^{76}$ Williams and Greenhaw, 29-30. 
Pullman Company were a distinct burden to black employees, the extent to which white control of black emotion extended outside an occupational context has yet to be substantially explored. Attention to emotional control brings a fuller understanding of the strands of oppression that characterized the Jim Crow era and how whiteness was defined and created, further expanding our understanding of the "culture of segregation" outlined by Grace Hale. ${ }^{77}$ The death of Wilkins and a consideration of porters' work more broadly make the case that racialized emotional control was another important method of building and enforcing ideas of racial difference, and is worthy of further scholarly consideration.

\section{AUTHOR BIOGRAPHY}

Dr. Rosemary Pearce has recently completed her PhD in the Department of American and Canadian Studies at the University of Nottingham. The author would like to thank the staff at the Newberry Library and Chicago History Museum for their help with locating the archival materials for this article, as well as Sharon Monteith, Peter Ling, Zoe Trodd, Timo Schrader, Alex Bryne and the anonymous readers of this article for their helpful comments. This work was supported by the Arts and Humanities Research Council (grant number AH/K503 186/I). Archival research was also supported by the US-UK Fulbright Commission's American Studies Research Grant.

77 Grace Elizabeth Hale, Making Whiteness: the Culture of Segregation in the South (New York: Panethon Books, 1998), xii. 